How to cite: Sfîcă, L., Ichim, P., Ion, C., Baltag, Șt.-E., Ignat, A. (2021) Filling the Gap of Meteorological Data Along the Prut River Valley, Romania - Cârja Experimental Weather Station (2013-2020). 2021 "Air and Water - Components of the Environment" Conference Proceedings, Cluj-Napoca, Romania, p. 169-180, DOI: 10.24193/AWC2021_16.

\title{
FILLING THE GAP OF METEOROLOGICAL DATA ALONG THE PRUT RIVER VALLEY, ROMANIA - CÂRJA EXPERIMENTAL WEATHER STATION (2013-2020)
}

\author{
Lucian SFIC $\breve{A}^{1}$, Pavel ICHIM ${ }^{1,2}$, Constantin ION ${ }^{3}$, Ștefan-Emanuel \\ BALTAG ${ }^{4}$, Alina IGNAT
}

DOI: 10.24193/AWC2021_16

\begin{abstract}
The study presents the results of the measurement realized at a meteorological weather station installed in Cârja village, situated in the valley of Prut river in the south-eastern tip of Vaslui county, Romania. The observations cover the interval from 2013 and 2020 and bring valuable data upon a region that lacks an official weather station. We present briefly the climatic profile of the weather station as reflected by the main climate elements (air pressure, air temperature, relative humidity, precipitation and wind) and a brief comparison with the data extracted from ROCADA database for the weather station location during the common period (January December 2013). As main climate features, we underline the mean air temperature of $12.0^{\circ} \mathrm{C}$ and the annual precipitation amount of $477.5 \mathrm{~mm}$. It is worth noticing that the difference between the in situ observations and the ROCADA database is below $1{ }^{\circ} \mathrm{C}$, being higher in summer time. Additionally, some details are given on those climatic parameters that present practical importance, such as rain intensity or wind power potential. The main conclusions of the study consists in (1) highlighting the very warm conditions specific for the last decade in the analysis region and (2) the relatively high agreement observed between in situ observations and the ROCADA database.
\end{abstract}

Keywords: weather station, Prut valley, network density, ROCADA, Romania.

\section{INTRODUCTION}

This paper aims to perform a climate analysis using meteorological data recorded at a meteorological station, which is part of an experimental observations network developed since 2012 in the region of Moldova between the Siret and Prut rivers (Ichim et al., 2014).

In the last years a decreasing number of official weather stations was observed, a fact that intensifies the lack of observations data (Krennert, 2018). Nowadays, the experimental weather stations are intensively used especially for monitoring weather conditions in remote areas (Zhu, 2019), or by independent users (Krennert, 2018). The use of crowdsourcing or experimental observation network data in

\footnotetext{
${ }^{1}$ Faculty of Geography and Geology, Alexandru Ioan Cuza University of Iași. (sfical@yahoo.com)

${ }^{2}$ Romanian Young Academy (RYA), University of Bucharest, Romania

${ }^{3}$ Faculty of Biology, Alexandru Ioan Cuza University of Iași.

${ }^{4}$ Marine Biological Station „Prof. Dr. Ioan Borcea” Agigea, Alexandru Ioan Cuza University of Iași.
} 
scientific papers or in filling the spatial gaps for meteorological information starts from 2010's in order to expand the coverage, as well as to enhance the performance of meteorological services (Zhu, 2019). The experimental observation networks or the crowdsourcing data is already a valuable tool for high temporal and spatial resolution, real-time data, especially in regions where few observations curently exist, addind value to science, tehnology and society (Muller, 2015).

It is known that, in order to cover the territory effectively with meteorological observations, the meteorological stations must be located in representative conditions and at relevant distance from each other, in order to ensure an optimal density of meteorological observations. The recommended density of meteorological stations is 1 meteorological station per $4000-5000 \mathrm{~km}^{2}$ (Gandin, 1970). This density may be even higher in mountain regions or for urban climate observations. In Romania, the average distance between meteorological stations is currently cca. $70 \mathrm{~km}$, reaching an optimal value during 1980-2000 interval when the average distance between the weather stations was approx. $50 \mathrm{~km}$.

Due to the fact that some regions in Romania are poorly covered with meteorological information, in 2012 we have intended to cover with meteorological data such a region situated in the middle sector of Prut valley. Through this, we aim to enlarge the regional knowledge of meteorological conditions by filling a consistent gap in weather stations density in north-eastern part of Romania. One of the main goal of this paper is to offer free access to meteorological data from this region that is poorly covered with day to day meteorological information.

\section{DATA AND METHODS}

The weather station is situated in a courtyard from Cârja village at $21 \mathrm{~m}$ absolute altitude above sea level $\left(46.148^{\circ} \mathrm{N}, 28.106^{\circ} \mathrm{E}\right)$ on the highest and most developed river terrace of the Prut river (Fig. 1). The data are collected at $2 \mathrm{~m}$ for air temperature and precipitation and $10 \mathrm{~m}$ for wind speed and direction, being collected at 1-hour time resolution.

For meteorological observations at this weather station we used a Davis automatic meteorological station (Davis Vantage Pro Cabled). The meteorological elements monitored and analyzed at this weather station are represented by air pressure, air temperature, air humidity, precipitations, wind speed, wind gust, wind direction. Davis weather stations work properly in a temperature range of $-40^{\circ} \mathrm{C}$ to $65^{\circ} \mathrm{C}$ and the sensors weather variables update interval is up to: 2.5 to 3 seconds for wind speed; 20 to 24 seconds for rainfall and 10 to 12 seconds for air temperature. The Davis weather stations sensors have a good precision and accuracy, according to the technical specifications (Table 1) (Davis Weather Station Technical Guide, 2010).

It is worth noticing that by applying Thiessen polygons on the density of official weather stations network of Romanian Meteorological Administration (tab.2), the resulting polygons corresponding to Bârlad weather station cover the largest surface for a single weather station in Romania. 


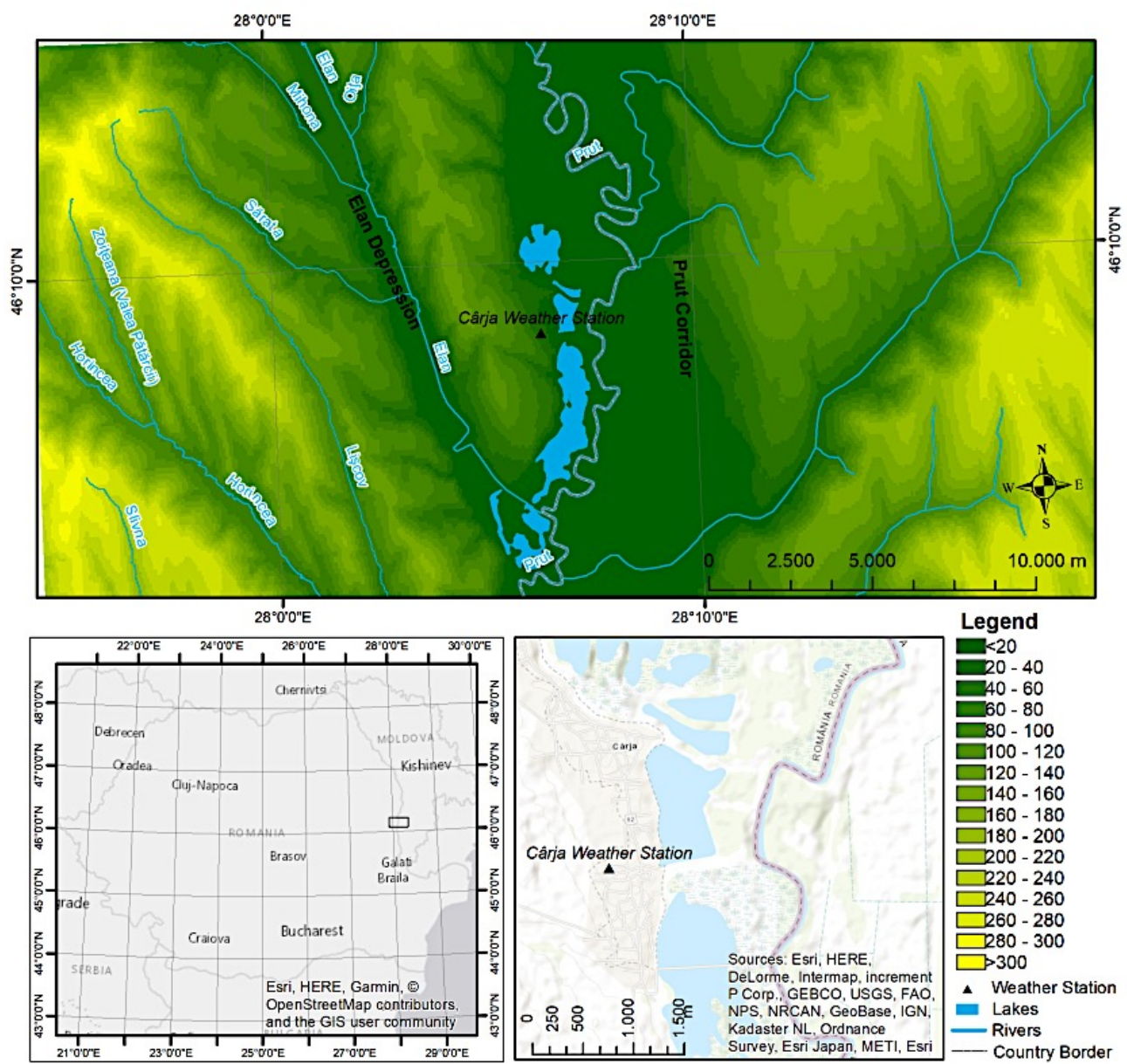

Fig. 1. Physico-geographical conditions of the study region with the detailed location of the Cârja weather station (Cârja WS)

When taking to account Cârja weather station (WS) instead, the four adjacent polygons (Vaslui, Bârlad, Tecuci and Galați) are significantly adjusted, a fact that underline, if not the need of a new weather station along the Prut valley, at least the usefulness of experimental weather observation in such a region (fig. 2).

The installed weather station collected data from January 2013 until December 2020. For the comparison with ROCADA database we have used the common period between January to December 2013, while for describing the climate condition in Cârja we have used the 8 full year period between January 2013 and December 2020.

Table 1. Technical specifications of Davis Weather Station (Technical Guide, 2010) 


\begin{tabular}{|c|c|c|c|c|}
\hline Variable & Update interval & Resolution & Range & $\begin{array}{c}\text { Nominal Accuracy } \\
(+/-)\end{array}$ \\
\hline $\begin{array}{c}\text { Air Pressure } \\
\text { (inside console sensor) }\end{array}$ & 1 minute & $0.1 \mathrm{hPa} / \mathrm{mb}$ & 540 to $1100 \mathrm{hPa} / \mathrm{mb}$ & $1.0 \mathrm{hPa} / \mathrm{mb}$ \\
\hline Outside Humidity & 1 minute & $1 \%$ & 1 to $100 \%$ & $2 \%$ \\
\hline Daily \& Storm Rainfall & \multirow{3}{*}{20 seconds } & $0,2 \mathrm{~mm}$ & to $999.8 \mathrm{~mm}$ & greater of $3 \%$ or 1 tip \\
\hline $\begin{array}{c}\text { Monthly \& Yearly } \\
\text { Rainfall }\end{array}$ & & $\begin{array}{c}0.2 \mathrm{~mm} \\
(1 \mathrm{~mm} \text { at totals over } \\
2000 \mathrm{~mm})\end{array}$ & to $6553 \mathrm{~mm}$ & greater of $3 \%$ of 1 tip \\
\hline Rain rate & & $0.1 \mathrm{~mm}$ & $2438 \mathrm{~mm} / \mathrm{hr}$. & $5 \%$ \\
\hline Outside Temperature & 10 seconds & $1^{\circ} \mathrm{C}$ & $-40^{\circ}$ to $+65^{\circ} \mathrm{C}$ & $0.3^{\circ} \mathrm{C}$ \\
\hline Wind Direction & 2.5 seconds & $1^{\circ}$ & $0^{\circ}$ to $360^{\circ}$ & $3^{\circ}$ \\
\hline Compass Rose & 2.5 seconds & $22.5^{\circ}$ & 16 compass pts & 0.3 compass pt. \\
\hline Wind Speed & 2.5 seconds & $0.4 \mathrm{~m} / \mathrm{s} ; 1 \mathrm{~km} / \mathrm{h}$ & $\begin{array}{c}0 \text { to } 809 \mathrm{~m} / \mathrm{s} \\
0 \text { to } 322 \mathrm{~km} / \mathrm{s}\end{array}$ & $\begin{array}{c}\text { greater of } \\
1 \mathrm{~m} / \mathrm{s} ; 3 \mathrm{~km} / \mathrm{h} \text { or } 5 \%\end{array}$ \\
\hline
\end{tabular}

We underline that since its publication ROCADA was widely used to assess climatic conditions in Romania for different climate elements or phenomena (Ionita et al., 2016; Sfîcă et al., 2017; Dobri et al., 2017, Bîrsan et al., 2019).
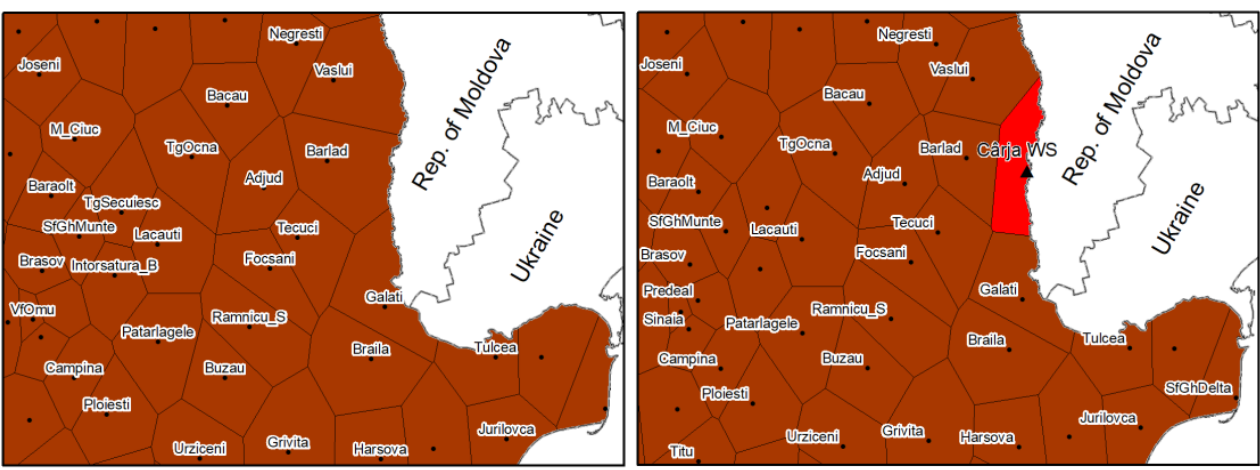

Fig. 2. Thiessen polygons distribution for weather stations density from National Meteorological Administration (NMA) network (left) and the distribution of Thiessen polygons by adding Cârja Weather Station (right)

Also, the same database was used in applied studies in the field of geomorphology (Niculiță et al., 2017), hydrology (Minea et al., 2017) or agroclimatology (Croitoru et al., 2020).

Table 2. Brief description of the nearest weather stations from Romanian Meteorological Administration (adapted after Cireș, 2004) 


\begin{tabular}{|c|c|c|c|c|c|}
\hline $\begin{array}{c}\text { Weather } \\
\text { Station }\end{array}$ & Lat & Lon & Alt $(\mathrm{m})$ & Period of functionning & $\begin{array}{c}\text { istance from Cârja WS } \\
(\mathrm{km})\end{array}$ \\
\hline Vaslui & $46^{\circ} 39^{`}$ & $27^{\circ} 43^{`}$ & 116 & $\begin{array}{c}1953-\text { present* } \\
1960-\text { present** }^{*}\end{array}$ & 63 \\
\hline Bîrlad & $46^{\circ} 14^{`}$ & $27^{\circ} 39^{`}$ & 172 & $\begin{array}{c}1940-\text { present* } \\
1962-\text { present** }^{*}\end{array}$ & 37 \\
\hline Tecuci & $45^{\circ} 51^{`}$ & $27^{\circ} 25^{`}$ & 60 & $\begin{array}{c}1959-\text { present* }^{*} \\
1961-\text { present** }^{*}\end{array}$ & 64 \\
\hline Galați & $45^{\circ} 30^{`}$ & $28^{\circ} 02^{`}$ & 69 & $\begin{array}{c}1956-\text { present* } \\
1968-\text { present** }^{*}\end{array}$ & 76 \\
\hline Huși & $46^{\circ} 41^{`}$ & $28^{\circ} 06^{`}$ & 84 & $\begin{array}{c}1946-1999^{*} \\
1975-1999^{* *}\end{array}$ & 59 \\
\hline
\end{tabular}

* entire period of observation; ** curent location of observation

\section{RESULTS AND DISCUSSIONS}

\subsection{Air pressure}

Monthly and annual average values of atmospheric pressure were calculated using both the ROCADA database for the period 1961 - 2013 and data recorded at the Cârja WS. Although during the year the variations of the monthly means of the atmospheric pressure are relatively small, the influence of the air pressure on the other climatic parameters is important by its role for the atmospheric circulation at local and regional level (Climate of Romania, 2008).

According to Climate of Romania (2008), the estimated multiannual average air pressure for the low region of the Prut Valley records values of approximately $1017 \mathrm{hPa}$ for 1961 - 2000 interval and 1016,7 hPa for $1961-2013$ interval according to the ROCADA database (Dumitrescu and Bîrsan, 2015), both values being very close to that recorded in-situ between 2013-2020 (tab. 3).

For the analysis of the diurnal variations of the atmospheric pressure we used the hourly data for characteristic months (January, April, July and October), recorded at the Cârja WS. In this regard, a classical variation is observed (fig. 3 ).

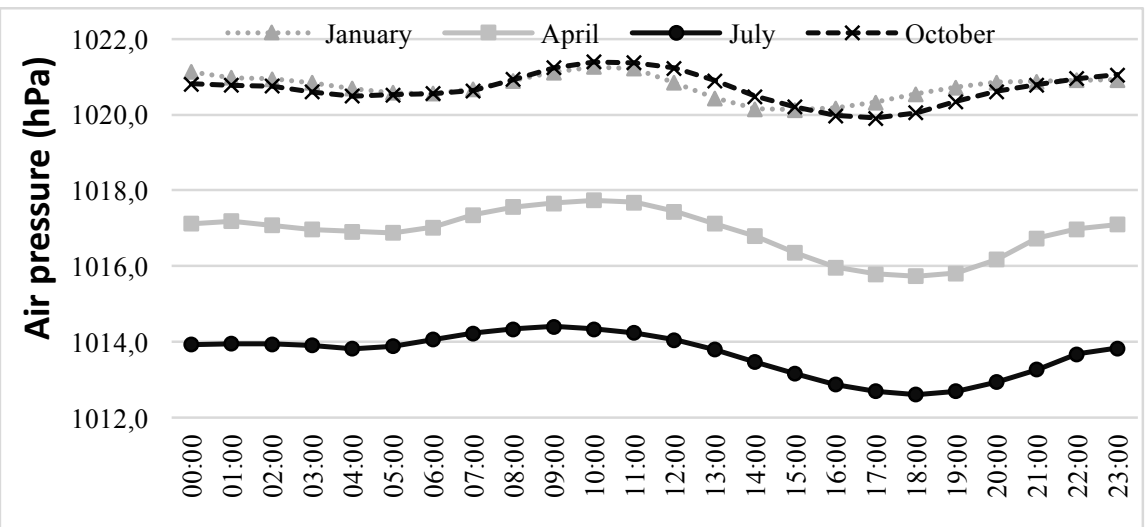

Fig. 3. Mean hourly pressure in January, April, July and October at the Cârja WS between 2013-2020 


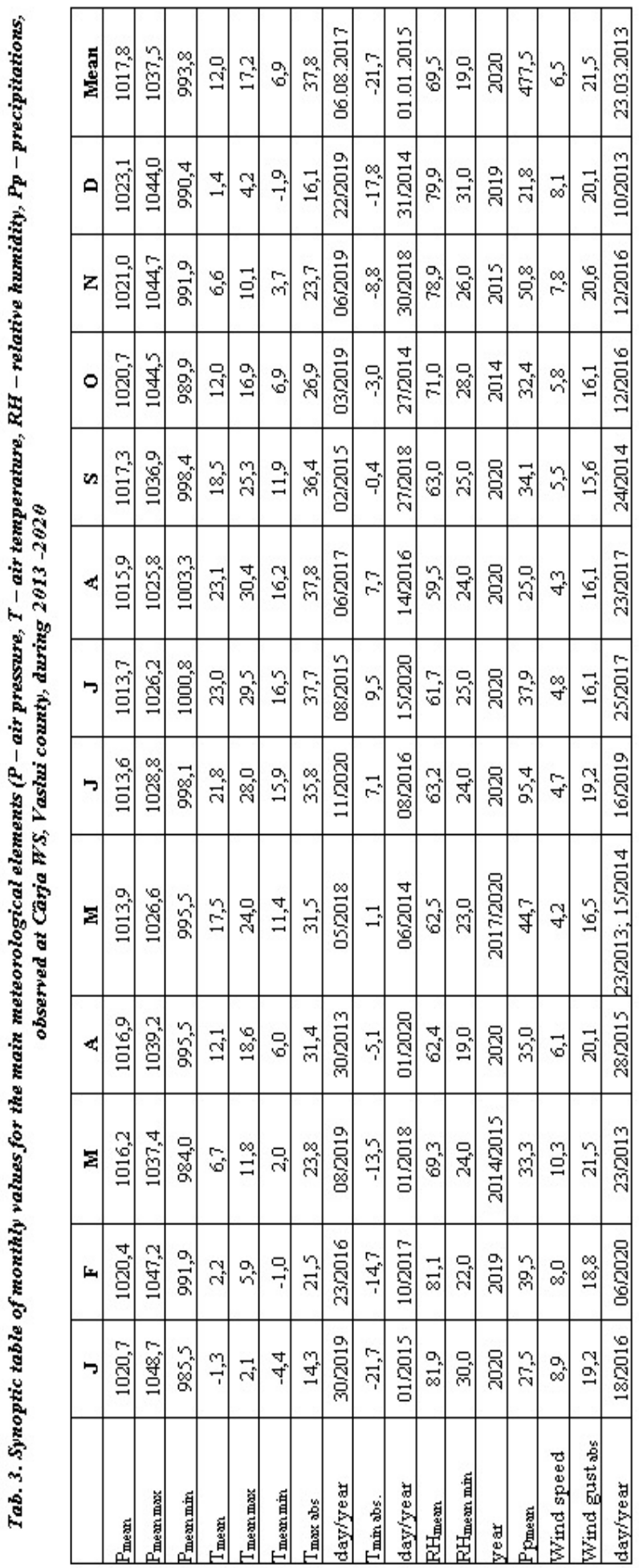


There are two maximums (9-10AM and 11PM-01AM) and two minimums (5-6 $\mathrm{PM}$ and 4-5AM). The main minimum is reached in the late afternoon and the main maximum right before noon, as a lagged effect of the air temperature variations. In the summer months, the main noon low occurs about two hours earlier.

\subsection{Air temperature}

To complete the data series and analyze the air temperature variation, the air temperature data for the common time series were compared between the the ROCADA database and the data series recorded at Cârja WS between January and December 2013. In figure 4 it can be observed that the interpolated data extracted from the ROCADA data series differs slightly compared to the data recorded within the Cârja WS. The mean difference in air temperature between the ROCADA database and recorded at Cârja WS is $+0.4{ }^{\circ} \mathrm{C}$ for the entire year. The differences are higher between July and September when they are close to $1^{\circ} \mathrm{C}$, and lower during months of cold season when they are below $0.3^{\circ} \mathrm{C}$. These differences follows the same patterns for means, maximum means and minimum means values.
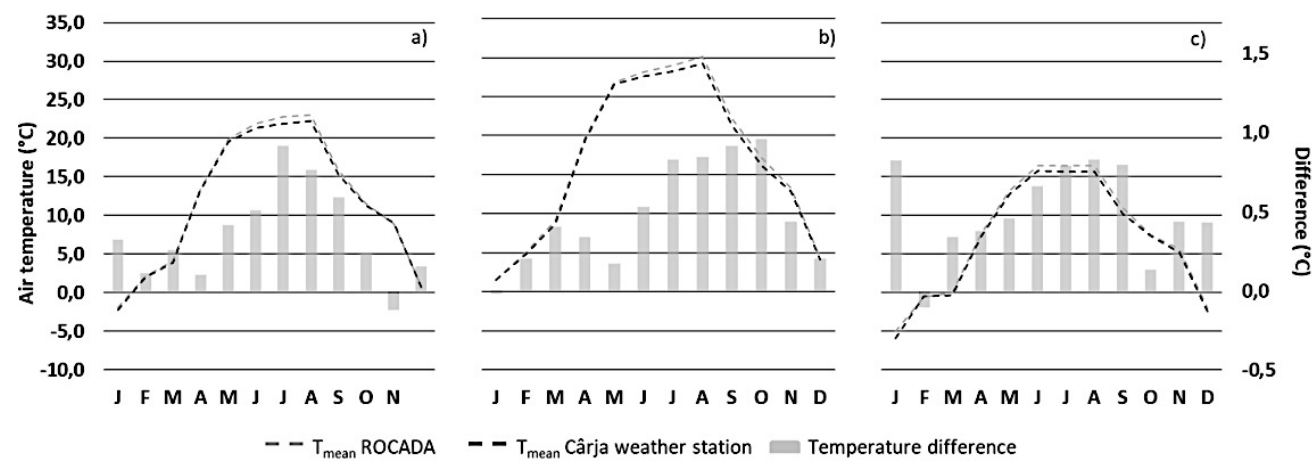

Fig. 4. Monthly mean, maximum mean and minimum mean air temperature and the differences between ROCADA database and data recorded at Cârja WS between January and December 2013

Generally, these differences could represent both an effect of shadowing effect by buildings and trees in the courtyard where the weather station is installed, but also a hint for a slight overestimation of air temperature values on ROCADA database for the plain regions that are not properly covered with official weather measurements.

According to the ROCADA database, the mean multiannual air temperature interpolated between 1961 and 2013 for the point indicating Cârja WS was $10.8^{\circ} \mathrm{C}$. From our meteorological observations, the mean air temperature reached $12.0^{\circ} \mathrm{C}$ (fig. 5), the difference representing mainly the increase in the air temperature manifested in the last 8 years (fig 5 ).

According to Climate of Romania (2008), the highest values of the daily mean temperature are recorded in July. Instead of this, the mean daily temperature values calculated for Cârja WS highlights the maximum shifted in the first part of August. 
During the hottest days of the year, the mean air temperature reaches at Cârja $24^{\circ} \mathrm{C}$, while at annual level the mean air temperature in this interval can reach even $28^{\circ} \mathrm{C}$. As regarding the coldest interval of the year, this is represented by January, with mean air temperature reaching $-4^{\circ} \mathrm{C}$. The variability of daily air temperature is higher in winter than during summer. Thus, while during the warmest interval in August the mean air temperature ranges between 20 and $28^{\circ} \mathrm{C}$, during the coldest interval in January the mean air temperature ranges between $-10^{\circ} \mathrm{C}$ and $6^{\circ} \mathrm{C}$.

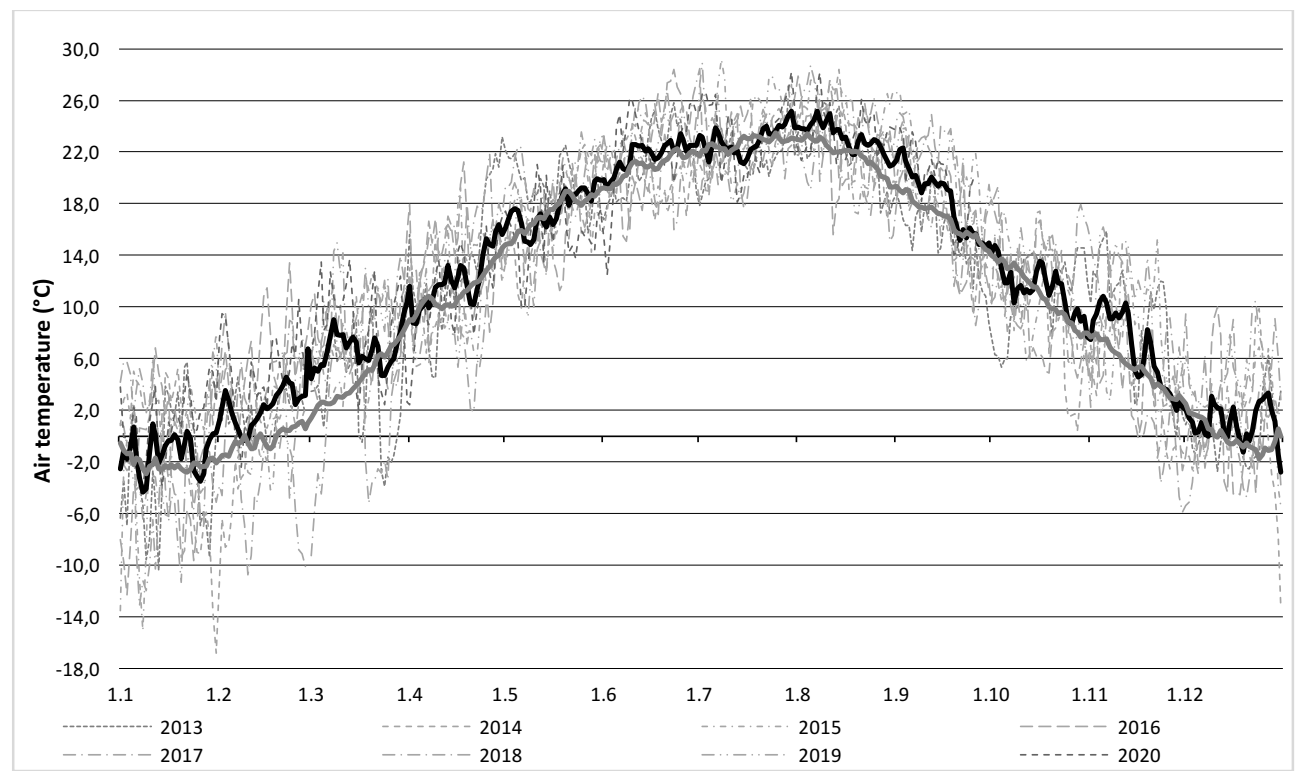

Fig. 5. Daily mean air temperature at Cârja WS for 2013-2020 and the long-term ROCADA daily mean (1961-2013)

Comparatively to data extracted from ROCADA database we can observe that the mean air temperature for Cârja WS (2013-2020) highlights some intervals during the year that seem to be more sensitive to the increase in air temperature. First interval is represented by February-March, with mean air temperature higher by $4^{\circ} \mathrm{C}$ than the ROCADA mean for 1961-2013. A second similar interval is represented by August-September, while the third interval resumes the late autumn and December. In brief, it is hard to say if these differences are the result of the regional and global signal of air temperature increase or a climate feature of the last decennia.

\subsection{Relative humidity}

Seasonal variation of relative humidity is influenced by altitude, air temperature and distance from the water bodies. For Cârja WS the annual mean relative humidity for $2013-2020$ was $70 \%, 5 \%$ below the mean extracted from ROCADA database for 1961-2013. This difference can be an effect of various influencing 
factors as the errors of ROCADA interpolation on the region or the sensitivity of the hygrometric logger of Cârja WS, but even so they are in line with the increase in air temperature over the region.

At annual level (tab. 3), while the mean monthly relative humidity reaches its maximum in January $(81.9 \%)$ and the minimum in August $(59.5 \%)$, in direct relation with the air temperature variation, the absolute minimum value of air relative humidity of $19 \%$ was recorded in April.

\subsection{Precipitation amount and intensity}

Since the rain gauge of Cârja WS does not melt the snow, the accuracy of the data regarding the precipitation amount during winter is not very high. Despite that, we should underline that the winter from 2013 to 2020 in the region were not characterized by long period of winter days combined with massive snow accumulation, so that the snow fallen in the region melted in short time after their accumulation, permiting the recording of the precipitation amount resulted from snow. However, this technical problem can be the cause for a mean precipitation amount for 2013-2020 which is lower than in Galaţi $(477,5 \mathrm{~mm}$ and $514 \mathrm{~mm}$, respectively). For this reason, our data for precipitation amount could be used with confidence especially for the interval from April to October when the precipitation are given exclusively by rain (fig. 6).

During this warm period of the year we remark the high amount of precipitation in June $(88 \mathrm{~mm})$, as result of a couple of such months recording extremely high amount of precipitation (193 $\mathrm{mm}$ in June 2019 or $180 \mathrm{~mm}$ in June 2013). Since the first part of the summer is very humid, August and September recorded small mean amount of precipitation. Combined with the air temperature, reaching higher values than long-term mean in this period, this lead to increased aridity in the region in late summer and early autumn, a feature that could represent the main shift of climate in the region during the present climate change.

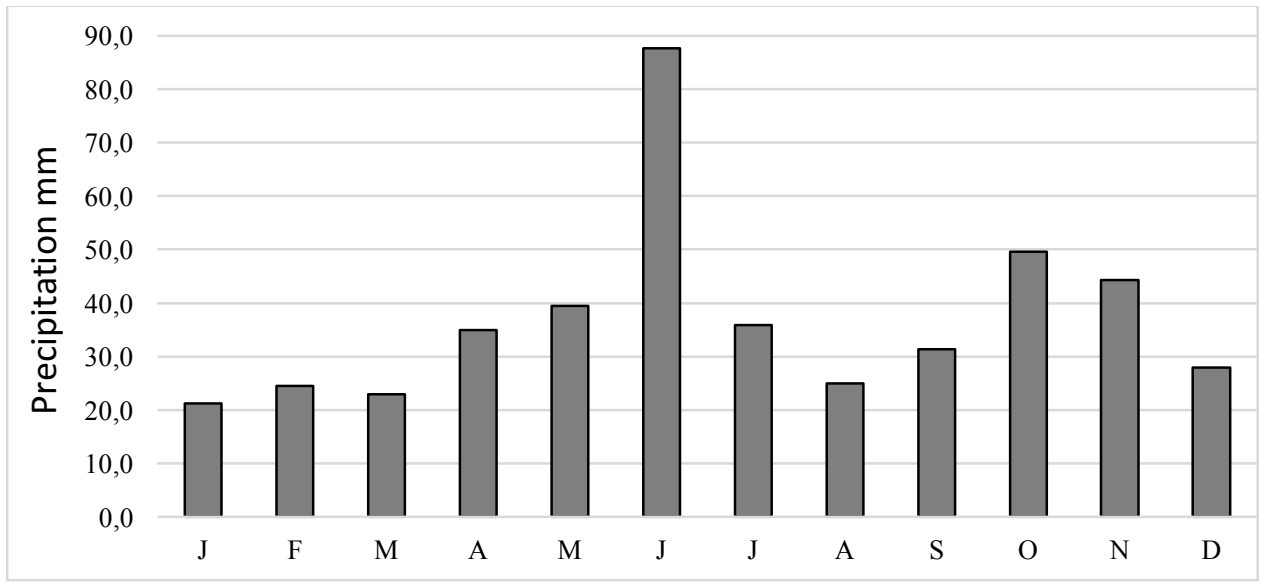

Fig. 6. Monthly variation of precipitation amount at Cârja WS (2013-2020) 
At hourly level (tab. 3), the data regarding the amount of atmospheric precipitation during April-October offers a comprehensive image on the rain intensity, a parameter of high interest for rain erosivity, a major problem in the region of Moldavian Plateau (Bucur et al., 2011, Mega and Damian, 2020). June recorded for 2013-2020 the highest intensity of rain amount per hour (34.6 mm), but values over $10 \mathrm{~mm} /$ hour are recorded in all months between May and October between 18 and 21 .

Table 4. Maximum hourly intensity of rain for each 3 hours intervals at Cârja WS (20132020)

\begin{tabular}{|c|c|c|c|c|c|c|c|c|c|}
\hline & $\mathbf{0 0 - 0 3}$ & $\mathbf{0 3 - 0 6}$ & $\mathbf{0 6 - 0 9}$ & $\mathbf{0 9 - 1 2}$ & $\mathbf{1 2 - 1 5}$ & $\mathbf{1 5 - 1 8}$ & $\mathbf{1 8 - 2 1}$ & $\mathbf{2 1 - 0 0}$ & Max mm/h \\
\hline April & 5.8 & 4.6 & 4.3 & 3.1 & 4.1 & 1.5 & 5.2 & 3.6 & $\mathbf{5 . 8}$ \\
\hline May & 14.0 & 2.0 & 8.8 & 5.1 & 2.0 & 9.4 & 8.6 & 15.2 & $\mathbf{1 5 . 2}$ \\
\hline June & 5.8 & 5.6 & 5.1 & 7.1 & 29.2 & 31.4 & 34.6 & 11.2 & $\mathbf{3 4 . 6}$ \\
\hline July & 5.1 & 5.1 & 11.8 & 1.5 & 4.6 & 19.3 & 10.4 & 12.8 & $\mathbf{1 9 . 3}$ \\
\hline August & 9.6 & 14.2 & 19.6 & 4.0 & 3.6 & 7.4 & 17.4 & 7.8 & $\mathbf{1 9 . 6}$ \\
\hline Sept. & 4.2 & 20.4 & 25.4 & 14.6 & 1.0 & 7.0 & 19.6 & 17.0 & $\mathbf{2 5 . 4}$ \\
\hline October & 8.0 & 5.3 & 14.0 & 6.4 & 8.0 & 8.0 & 11.0 & 10.2 & $\mathbf{1 4 . 0}$ \\
\hline Max $\mathbf{~ m m / h}$ & $\mathbf{1 4 . 0}$ & $\mathbf{2 0 . 4}$ & $\mathbf{2 5 . 4}$ & $\mathbf{1 4 . 6}$ & $\mathbf{2 9 . 2}$ & $\mathbf{3 1 . 4}$ & $\mathbf{3 4 . 6}$ & $\mathbf{1 7 . 0}$ & \\
\hline
\end{tabular}

\subsection{Wind}

The eastern part of Romania records the maximum mean wind speed in Romania (Rusan, 2010). Moreover, the Prut valley leads by its north-south orientation to a concentration of the wind along this axis (fig. 7). The mean monthly wind speed exceeds $7 \mathrm{~m} / \mathrm{s}$ from November to March, with the maximum in this month at $10.3 \mathrm{~m} / \mathrm{s}$. Actually, this month recorded also the maximum wind gust of $21.5 \mathrm{~m} / \mathrm{s}$ (tab. 2).

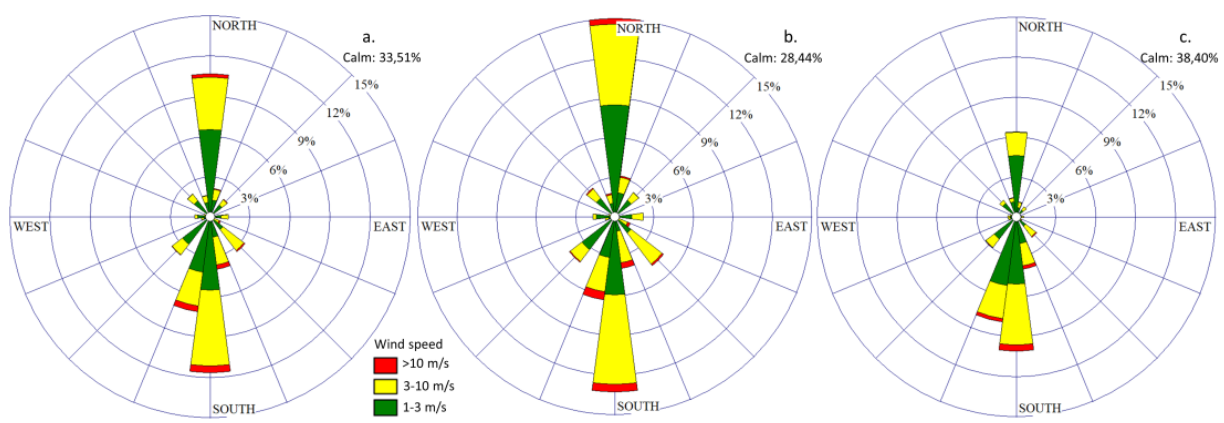

Fig. 7. Wind roses for annual (a), cold semester (b) and warm semester (c) 


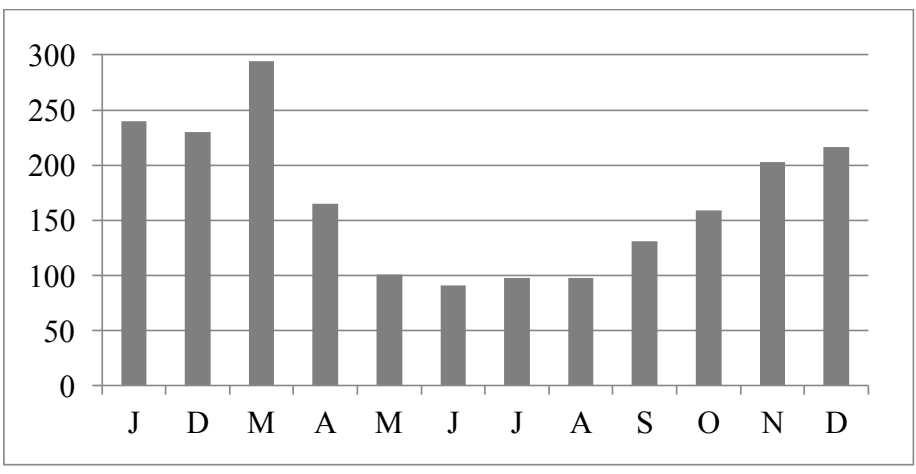

Fig. 8. The mean monthly number of hours with wind speed $>3 \mathrm{~m} / \mathrm{s}$ at Cârja WS (2013-2020)

Based on the hourly observations of wind speed we observed that during the year almost $25 \%$ of time the wind presents good conditions in term of wind power (wind speed $>3 \mathrm{~m} / \mathrm{s}$ ). The maximum potential in this regard is reached during cold season with the peak in March, when almost $40 \%$ of time the wind speed is higher than $3 \mathrm{~m} / \mathrm{s}$ at hourly level.

\section{CONCLUSIONS}

During the current time of big data, the meteorology faces the challenge of the variety of observations techniques. On one hand the researchers in the field of meteorology and climatology need to have their own contributions in observational meteorology by implementing new points of monitoring local conditions. On the other hand, the operational meteorologists have to develop their capacity to assimilate the meteorological data obtained from independent observations.

In the current article, we presented the main feature of the climate profile of Cârja WS that collected hourly data on air pressure, air temperature, relative humidity, precipitation amount and wind speed and direction from 2013 to 2020 . The recorded data bring useful meteorological information for the lower Prut river basin, a region that was poorly covered with in situ measurement until the installation of this weather station.

It is imported to notice that the monthly values for 2013-2020 are available for free downloads, with mandatory acknowledgement for this article in case of their use for scientific purposes. Thus, in order to download the monthly data for the climate elements presented here for Cârja WS for 2013-2020, please access the following link: https://www.meteomoldova.ro/2021/02/wether-data-carja-2013-2020/

\section{References:}

Dumitrescu A., Birsan MV. (2015), ROCADA: a gridded daily climatic dataset over Romania (1961-2013) for nine meteorological variables. Nat Hazards 78, 1045-1063. doi: 10.1007/s11069-015-1757-z 
Bîrsan, M.V., Micu, D.M., Niță, I.A., Mateescu, E., Szep, R., Keresztesi, A. (2019), Spatiotemporal changes in annual temperature extremes over Romani (1961-2013)

Bucur, D., Jităreanu, G., Ailincăi, C., (2011), Soil erosion control on north-east Romania. In book: Soil erosion issue in agriculture, doi: 10.13140/2.1.2349.1521

Cireș, C., (2004), Monografia stațiilor meteorologice din Moldova, partea I, Iași, manuscript.

Croitoru, A.-E., Man, T.C., Vâtcă, S.D., Kobulniczky, B., Stoian, V. (2020), Refining the Spatial Scale for Maize Crop Agro-Climatological Suitability Conditions in a Region with Complex Topography towards a Smart and Sustainable Agriculture. Case Study: Central Romania (Cluj County). Sustainability 12, 2783. https://doi.org/10.3390/su12072783

Dobri, R.V., Sfîcă, L., Ichim, P., Harpa, G.V. (2017), The distribution of the monthly 24hour maximum amount of precipitation in Romania according to their synoptic causes. Geographia Technica, 12(2): 62-72, doi: 10.21163/GT_2017.122.06.

Gandin L.S., (1970), The planning of meteorological station networks, Published by: World Meteorological Organization, 1970, Collection and Series: No. 265 Technical Note

Ichim P., Apostol L., Sfîcă L., Kadhim-Abid Adriana-Lucia, Istrate V. (2014), Frequency of thermal inversions between Siret and Prut rivers in 2013, Present Environment \& Sustainable Development, Vol. 8, no. 2, Iași, doi: https://doi.org/10.2478/pesd-2014-0040

Ionita, M., Scholz, P., Chelcea, S. (2016), Assessment of droughts in Romania using the Standardized Precipitation Index. Natural Hazards, 81: 1483-1798, doi: 10.1007/s11069-015-2141-8.

Krennert, T., Pistotnik, G., Kaltenberger, R., and Csekits, C.(2018), Crowdsourcing of weather observations at national meteorological and hydrological services in Europe, Adv. Sci. Res., 15, 71-76, https://doi.org/10.5194/asr-15-71-2018.

Mega, M., Damian, A.D., 2020. Climate seasonality and its relevance for soil erosion during summer in extra-carpathian Moldova. Present Environment and Sustainable Development, 14(2): 1-13, doi: 10.15551/pesd2020142015.

Minea, I., Croitoru A.E. (2017), Groundwater response to changes in precipitations in north-eastern Romania. Environ. Eng. and Manag. Journal., 16, 3: 643-651.

Muller, C.L., Chapman, L., Johnston, S., Kidd, S., Illingworth, S., Foody A., Overeem Leigh, R.R. (2015), Crowdsourcing for climate and atmospheric sciences: current status and future potential, International Journal of Climatology, 35, 11: 3185-3203, doi: $10.1002 /$ joc. 4210

Niculiță, M., Andrei, A., Lupu, C. (2017), The landslide database of the North-Eastern Romania. Proceedings of the Romanian Geomorphology Symposium, 33rd edition, Iasi, 2017, 81-84, doi: 10.15551/prgs.2017.81.

Rusan, N. (2010), Wind energy potential in Romania. Rom. Journ. Geogr., 54, (1), p. 7788,2010 , Bucureşti.

Sfîcă, L., Croitoru, A.-E., Iordache, I., Ciupertea, A.F. (2017), Synoptic Conditions Generating Heat Waves and Warm Spells in Romania. Atmosphere, , 8, 50. doi: 10.3390/atmos8030050

Yifan Z., Zhang, S., Y., Li, Y., Lu, H., Shi, K., Niu, Z.(2019), Studies on CrowdsourcingAssisted Meteorological Knowledge Services (2011-2018), Institute of Software Intelligence and Software Engineering, Beijing Institute of Technology, doi: $10.1002 /$ gdj3.85

*** Climate of Romania, 2008, Editura Academiei Române.

*** Davis Weather Station Technical Guide https://www.davisinstruments.com/product_documents/weather/manuals/. Accessed on 10.01.2021 